\title{
OCULAR AND CUTANEOUS MYLASIS IN SHEEP IN SAUDI ARABIA
}

\author{
M. H. Abdally \\ Department of Microbiology and Parasitology. College of Velerinary Mojicine \\ and Animal Resources, KIng Falsal University, Al-Ahsa, Saudr Arabla \\ (abdalauth816yoo.eum)
}

\begin{abstract}
Three sheep were treated from cutaneous and acular myiasis at the Veterinany Teaching Hospltal King Falsal Universlty. Two animals were suffering from deep and smelly necrotized, molst cutaneous lesions on their hind quarters that reached the underlying musculative. The lesion of the third sheep was located th the left eye destroying the globe, By applying pressure to the affected skin. greylsh yellow $1 \mathrm{~cm}$ long fy maggots, tapering towards the mouth, began to exit the caulties.

The maggots were microsopically exambed and identufled as Lucllia sericata: Het. gen., the green botlle $f y$, and it was deternined that these were cases of $f y$-sorke. Afcer cleaning and disinfecting the lesions, anttparastitic medications were appiled toptcally and systemically, The antmals were aiso treated systemically with antiblotics. After 5 days of therapy the sheep were discharged. information from the field indtcates that cases of Jy strike are not uncommon in Al-Ahsa.
\end{abstract}

Key Words : Cutaneous mylasis, Ocular mylasis, Haenogram, KF U Vet. Teaching Hospulul.

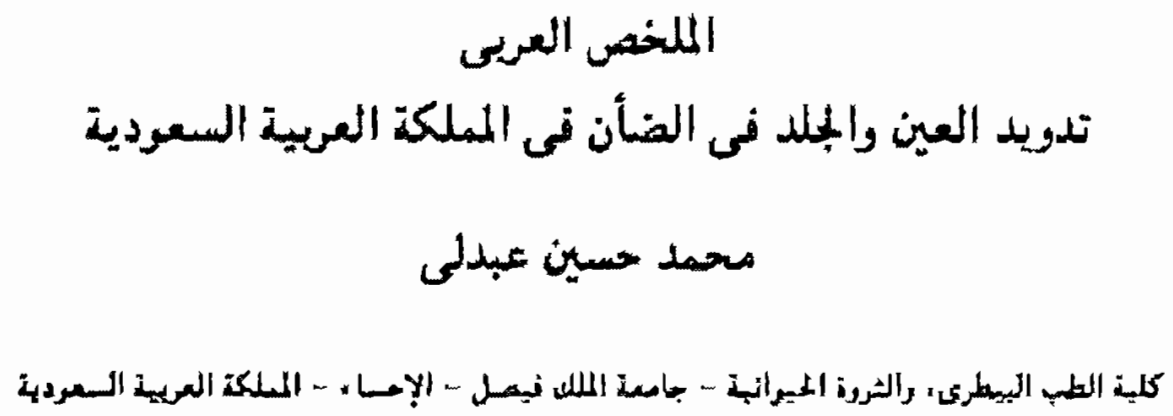

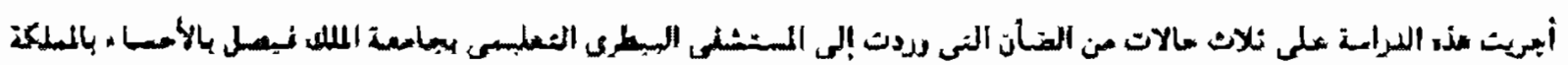

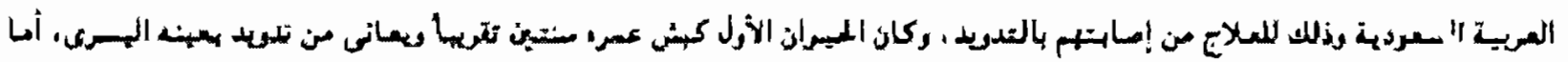




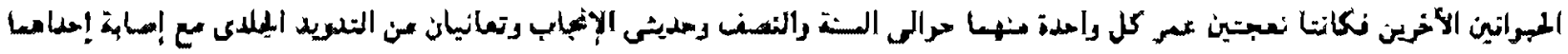

$$
\begin{aligned}
& \text { يإلنهابع فى المهبل. }
\end{aligned}
$$

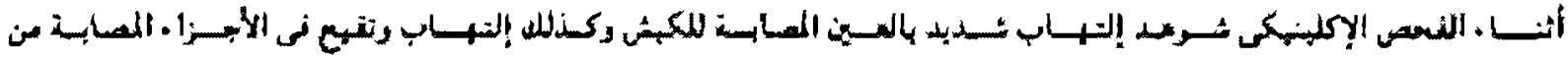

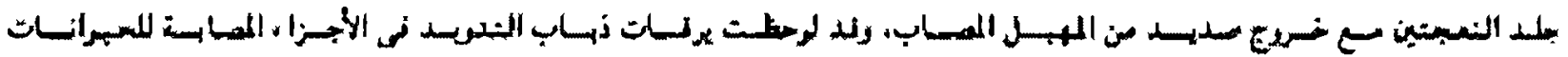

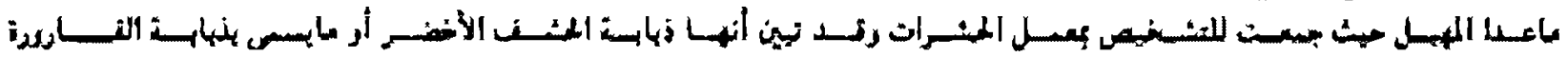

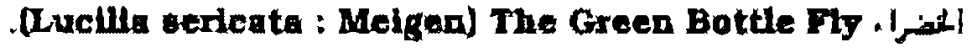

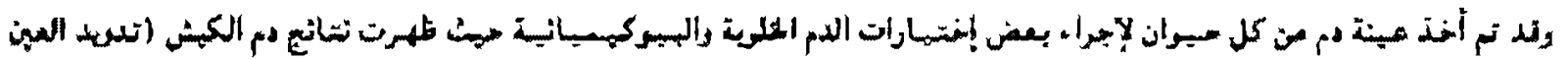

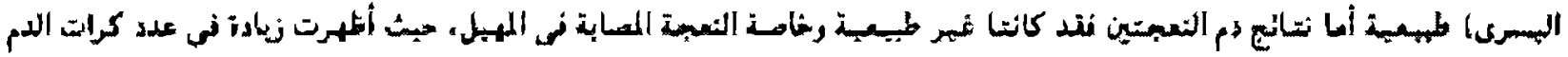

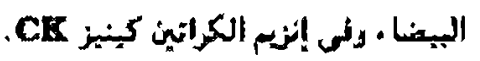

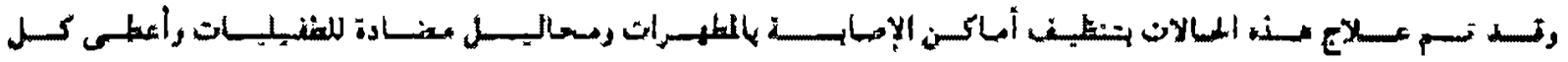

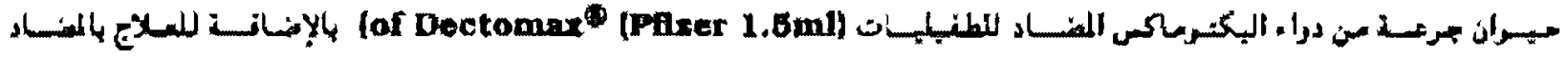

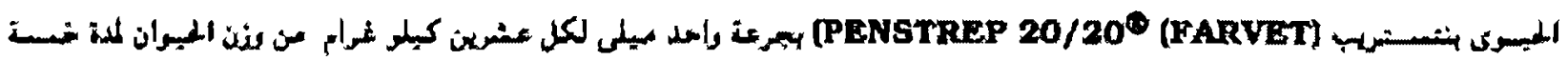

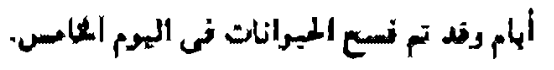

\section{INTRODUCTION}

Cutaneous mylasis is caused by liy speeies of the famlly Calliphorldae and they are divded into two maln groups. a primary species, which are able to initiate the disease. and a seeondary spectes, whleh requite a prewlous damage or infestation of the host by a primary species (Urquhart et al.. 1987). The secontdary spectes and new waves of the primary spectes are attracted to sheep skin lesions, primarlly by the odour that is emitted (Fenton of al., 1999; Martin and Altken, 2000; Btaric et al., 2002; Urquhart et al., 1987; Wall and Bmith, 1096). Although these Nies are facultative parasites and their maggots can develop off the host on cadavers and manure. the maggots of the specles Lucllla cupinna are an exceptlon and the almost exclustvely as parasites (0taric et al., 2002). Therefore this specles is eonsidered an obligate parasite by many authors (Redostle et al., 2000: martin and Altken 2000). Lucilia sericata and Lucllia cuprina are consldered as the matn primary spectes in central and westem Europe (staric et al., 2002). However their larvae are consldered as the most important causative agent of mytasls in troplcal and subtrupical reglons (Hira et al., 2004: Btaric ot al. 2002).

Mylasts caused by the obligate parasitic ny maggots of chrysomyta spp. eg C. bezzlana is also posstble tot be found in AL Ahsa since they were reported in Saudi Arabla (Almmad, 2002: Banaja and Ghandour, 1894; Heas and E1-8lbas, 1903). Maggots of these specles are also called screw worns and are the cause of large losses of farm animals (gturic ot a1. 2002). There are many writien reports emphasiging the great economic losses caused by cutaneous mylasis in sheep breedIng countrles, such as South Afica, New Zealand and Australla (8tarie et al., 2002: Urquhart et al., 1087). It is estlmated that in Australla 3,000,000 sheep die because of cu- 
taneous mylasis each year (Bowen et al., 1000). The prevalence of cutaneous mylasts In England and Wales is csumated at $1,6 \%$ of sheep, of whlch 12,000 die each year (French et al.. 1096). Besides mortallty, the disease causes other flnaneial loss as It also antects wool production, antmal growth and results in addituonal expenses due to the cost of prevention and santation (Starle et al., 2002; Urquhart et al., 1887).

\section{MATERIALS AND METHODS}

Owner' complaint and Physlcal examlnation:

Three sheep (from a fock of 130sheep) were brought to the Veterinary Teaching Hospital for treatment. They were one male Isheep A) suffering for ocular lestons in the left eye and two females (sheep $B$ and $C$ ) suffering from cutaneous lestons.

\section{Ocular mylasio :}

The Arst shecp (Shecp A) was about 2 years old ram had an irregular laceration on the lower eyc-lid, conjunctulus corneal opacicy and several maggots were seen actively motle. However physical examinations showed that the animal was generally nomal.

\section{2-The cutancous mylads :}

The other two sheep ( $B$ and $C$ ) were females and both had recently lambed. The owner nouced that they were restsess, netther eating nor carting for their lambs. The owner mentioned also that they had dirty wool on thelr heads and they were blung themseives on the hindquarters. He notlced that they had wounds which were infested with worms
In the area around the base of the tall. The affected area also had a disunct roting odour. Further examination of the sheep showed that their fleeces were unshorn, dense, humid and dirty on the surface. Onc shcep (sheep B) had a massive purulent vaginal discharge that solled the caudal part of the abdorntnal wall from both sldes.

During a detalled examtnation of the skin we found necrotlzed. molst. black skin with many small holes and few larger ones in the breeeh area. On each slde of the tall there were two deeper ulcerations (sheep B) nearly reached the muscular tissues. Many fly maggots were scen In the wounds of both animals. They were tapered towards the mouth and ranged from a few $\mathrm{mm}$ to $1.3 \mathrm{~cm}$ in length. Many nests were found in the fleece on the sacral and caudal parts of the lumbar area. They were round and approximately $1.3 \mathrm{~cm} \mathrm{tn}$ dlameter and full of hy maggots. Some of them had reached the skin causing esythenta. The two anlmals had pyoderma on the ventral part of the tall and around the anus and bout of them were tachycardic labove 90 beats per minutel, tachypnoelc (above 80 breaths per minute) and febrtle (body temperature above $\left.40^{\circ} \mathrm{C}\right)$.

\section{Hematology Test :}

Blood samples were collected from the jugular veln of the thrce sheep for complete tremogram as well as measurcment of the activtty of the creatnine kInase enzymc.

\section{Identification of the Dles :}

Larvae were collected from the lesions of the three animals in order to be kdenuned in the entomology laboratory. Sone of them were 
examined under the stereomicroscope. Others were reared for adult examination. The work was done according to Soulsby (1986) and walker (1804).

\section{Treatment :}

In case of cutaneous myiasts of sheep $B$ and $\mathrm{C}$, treatment of the antmals was performed according to starle et al (2002). The affected areas were first shorn and then washed with antparasitic solution which was made of 90 grams trichlorofon (Neguvon from Bayer) until it was free of all dirt, necrotIc tlosue and visibie fly maggots. The affected eyc of the male shoep $A$ wats veleaned fiom maggots and necrotle tissues and washed wth eye disinfectant solution (15\% Boric acid). Then all the three sheep were gyen 1.5 $\mathrm{ml}$ of Dectomax (PRzer; doramectln called tvermectins) subcutaneously in order to kill ny maggots that may have survived by burrowing into the Ussues. Because of the severty of the lestons of all the three animals they were given pendillin and streptomycin the form of PEN-STREP 20/20 (FARVET) at a

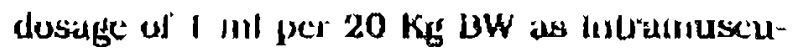
lar injection in single dose dally (SID) for 5 days.

\section{RESULTS}

\section{Phyulcal Examinatlon :}

The clinical pictures of the two female anlmals (Sheep $B$ and $C$ ) typically skdn mylasis whteh resulted as a reflex of bad management of the animals. The same reasons also lead to ocular mylasls of the rum (Sheep A). After receiving good managements treatments all the three arumals returned to their normal healthy clinical pletures.

\section{Hematology Test :}

Laboratory Investigation showed that the shecp $B$ had a slightly Increased hematucrit level $(40.1 \mathrm{l} / 1)$, slight leucopenla $4.8 \times 109 / 1)$ and thrombocytopenta $\left(10^{5} \times 10^{3} / \mathrm{mm}^{3}\right)$. Sheep A had a slightly roduced number of erythrocytes $\left(7.710^{6} / \mathrm{mm}^{3}\right)$, a decreased hemoglobin level $(9.2 \mathrm{~g} / 1)$ and higher than normal number of segrnented granulocytes $50 \%$. The other $\mathrm{CBC}$ and differential white blood count values were normal. The acturity of the creatunine kInase enzyme was elevated in both sheep. $163 \mathrm{U} / \mathrm{I}$ in sheep $\mathrm{C}$ and $151 \mathrm{U} / \mathrm{l} \mathrm{in}$ sheep B. In case of ocular mylasis (sheep A the licamiatulergy results were seen quite normal (see table 1).

\section{Identifleation of the Iles:}

The larvae and adult flies were identifed as the green bottle fly, luclllia sericata Melgin.

\section{Treatment :}

Two days after the therapy the body temparature of the two sheep $\mathrm{B}$ and $\mathrm{Cl}$ had returned to normal and there were no magoots found during an hispertion of this allecied skin and neece and the necrotized skin dried and heeled quickly. Three days later the necrouc skin had begun to peel. revealing the wable skin under it. The purulent vaginal dis. charge or sheep $B$ completely ceased aiter four days. The ocular leston of sheep A responded to treatment after three days. Animals were discharged after flve days.

\section{DISCUSSION}

The clinical picture which was described in Is typlcal of skin irylasis. Stark and his colLaborators (2002) reported a simllar case in 
Slovenla whereas 2 sheep of a bigger llock (250 sheep) were alfected in the autumn following their first lamblng. In fact cutaneous mytasls most commonly affects the hindquartera duc to the anlmal's urine. frees and loehla beside the bad and moist conditions which result from the poor animal mariagement (Radostlts et, al., 2000; Fenton et. al., 1988; James et. al., 1994). This together with warm temperature and rains will congtitute an ideal environment for the development of the eggs and maggots of mylagls flles Martle and Altken, 2000; French et. al. 1980; Urquhart et al. 1887). In (act all the faetors that predispose sheep to culaneous mylasis were found in these three cases. The two female sheep had just lambed, they were unshorn, unproteeted by Insecticides. beside the weather was warm and humld. Seeondary baeterial invaders may aggregates skin lesions caused by cutaneous mytasis (startc et al.. 2002). The ram may get the Infection in his eye from them. This together with the Subsequent waves of ny-larvae constant infestations may extend the skdn lesions (Btaric et al. 2002). This may infect other parts of the skin or other orgarns of the same animal or other animals and it showed how the ram was affected in his eye. Fly maggots also excrete ammonta whlch may be absorbed by the skin, leading to secondary afflietion. For this reason the heavily infested antmals may show signs of general disturbanre, debilitation and a loss of condition (8tarie et al., 2002). Therefore this is the cause which makes sheep to ehange their usual behavior $(0$, Brien et. al., 1987). This explains how the ram was nearly quite and calm. whlle the two ewes were restless. These changes were relleeted in the haemogram of the three animals (see table 1). The ralscd activity of the creatinine kinase enzyme (CK) could be a consequence of the ussue damage caused by the cutaneous mylasis (Staric tal., 2002). The pliysical ellorts assoclated with animal actlvities $\mathrm{cg}$. Inoving the shecp Irom pasture to house may lead to ralse It (5tarde et al., 2002), In our cases only the ewes wh cutaneous mylasis showed the ralsed CK (Sheep B 151 U/I and Sheep C 163 U/I I whlle the ram (sheep A I was $145 \mathrm{U} / \mathrm{I}$ labout the normal : $120 \mathrm{U} / \mathrm{ll}$. however all the anlmals were moved from the same place and brought to the hospital. Therefore activity is not a stronger reason behind the ralse of $\mathrm{CK}$ thasl culaneous mylasts. This is supported by some authors who had also deseribed the similar clinical pleture of sheep sufferng from cutaneous mylasis (Radostite et. al. 2000; Alello, 1998; 0,Brien et. al. 1997). Therapy of alfecled animals should be adjusted for each case according to fts condition and sttuation. For example in mildly infested animals without visible skin lesions. just shearing the wool from the affected area can be enough in favorable conditjons (8tarte t al., 2002). However in areas where cutaneous mylasls is more widespread. the wool is routinely shorn from the sheep hindquarters and the procedure is called tagging or crulching (Redostits et al., 2000). In fact this will prevent the eggs or maggots to develop as they desireated and not developed (Starte et al., 2002). Th1s will pratect the animals from being ny-struck in the hindquarters for about 6 to 8 weeks (Radontt et al., 2000; Aello, 1998). It is well known that cleaning and shearng the whole sheep prevents strlkes on other parts of a body. while shearing the head or around prepuee prevents strikes on the head or ptzile and this would best cure for most of the mild 
cases and by correctly tming the shearting of sheep, it would also be a good way to prevent ny-strikes of predisposed sheep (Staric et al.. 2002). Practlcally this ts the most correct way to prevent eutaneous mylasis in Saudt Arabla.

For more heavlly alfected sheep It Is recommend, in addition to the shearting, a topleal treatment of the affected area with both larvicides and insecticldes. In case of sheep with deep cutaneous mytasis wounds it is reoommended to be thoroughly cleanged with disinrecting agents and treated with broad spectrum antblotics as it was followed in our cases where all sheep respondcd very well to our therapy and completely recowered. However in more refraetory infections, this should be done with antlblotics following eulturing and sensitivity testing. Supportive therapies like Infusions. analgesics and antlInllammatory mediclnes could also be given to more heavily affected animals to help stimulate recovery (Starlc et al., 2002).

Preventlve measures against cutancous mytasis such as cleansing shearing the sheep. tall docking and hyglenic lambing etc. can reduce a sheep's suseepubility to ny strike or reducing the fly population with the use of inseetieldes and larvicides or with ge- netically altered and stenle male fles can also prevent fly strikes (Radoatits et al., 2000; Starte et al 2002). We are or the opinion that myiasis (espectally the cutaneous inylasts) should get more attention because of the increasing number or animals(partleularly sheepl in A-Atisa and the losses that It can cause every year according to the report of The Veterinary Teaching Hospltal (2007). Therelore a strategy lor preventing and combating this disease should be established Saudi Arabla and sheep herds owners should be more informed on how to reeognize and prevent the disease.

\section{Acknowledgemeats :}

Thanks ane due to our colleagues at the vetertrary Teaching hospltal for sending the animals for treaunent. Thanks also expressed to the sheep owner Al-Shalkh A M Al-Bogomi. I am grateful to Mr Matar Monadl Al-Enazl who helped during treatment. My deep thanks are due to Dr. Badr Al-Hamdan medicine diagrostic lab. for hematology tests.

Finally $t$ wish to express my great appreciaton to Prolessor Ramadan O. Ramadan, proLessor of surgery and Prolessor Taha A. Fouda, professor of medicine for their invaluable comnents. 
Table 1: The hematological values and activity of creatinine kinase in the thrce sheep $A, B$ and $B$.

\begin{tabular}{|l|c|c|c|c|}
\hline The Parameters & \multicolumn{3}{|c|}{ The Tested Animgls } & Normal values \\
\cline { 1 - 4 } & Sheep A & Sheep B & Sheep C & \\
\hline Erythrocytes & 7.8 & 7.7 & 10.18 & $7.8-13 \times 106 / \mathrm{mm} 3$ \\
\hline MCV & 281 & 40 & 39 & $28-44$ n \\
\hline MCHC & 31 & 30 & 30 & $31-34$ g/dI \\
\hline MCH & 8 & 12,0 & 11,8 & $8-12 \mathrm{pg}$ \\
\hline Hb & 9 & 9.2 & 12 & $9-14.7 \mathrm{~g} / \mathrm{dI}$ \\
\hline Ht & 0.27 & 30.7 & 40.1 & $0.27-0.45 \mathrm{~V}$ \\
\hline Thrombocytes & 250 & 294 & 105 & $250-750 \times 103 / \mathrm{mm} 3$ \\
\hline Leucocytes & 5 & 5.9 & 4.8 & $5-12 \times 109 / 1$ \\
\hline Leucocytes & 50 & 49 & 67 & $50-73 \%$ \\
\hline Seg. gran. & 17 & 50 & 30 & $17-45 \%$ \\
\hline Bands & 3 & 0 & 0 & $0-3$ \\
\hline Eosinophils & 2 & 1 & 3 & $1-10 \%$ \\
\hline Monocytes & 0 & 0 & 0 & $0-6 \%$ \\
\hline Basophils & 0 & 0 & 0 & $0-2 \%$ \\
\hline CK & 125 & 151 & 163 & to 120 U/1 \\
\hline
\end{tabular}

$A=$ Male sheep with ocular myiasis

$\mathrm{B}=$ Female sheep with cutaneous myiasis and vaginal infection

$C=$ Female sheep with cutaneous myiasis only 


\section{REFERENCES}

Alello B. E. (1898) : The Merck velerinary manual. $8^{\text {th }}$ ed. Whitehouse stathon: Merck \& Co.. Inc. 650-2.

Althmed A. M. (2002) : Incidence of Mylasts in Sheep Caused By Chrysomya Bezzlana In Saudl Arabla. J. Kung Saud Univ. Volv 14 Agrk. Scl.: 2, 91-94.

Banaja, A A and Ghandour, A $M$. $(1904)$ : A review of Parasites of Camelo (Camelus dromedarlus) In Saudi Arabla. J. K. A. U. Scl. Vol.6, 75-86.

Bowex, F. L.; Fibara, P.i Junquera, P.: Keevere, D. T.; Mahoney, R. $H$. and Schmld, H. R. (1998) : Long-lasung preventorn agatnst blowny strike using the Insect growth regulator dicyclanil. Aust Vet J; 77 (7): 454-60.

Eema, N. M. and El-Sibac, M. M. (1993) : Population dynamics of some synanthroplc fly specles in different habitals in Buraydah. Saudl Arabla. J. Egypt. Soc. Prasitol.; 23, $133-40$.

Penton, $A_{i}$ Wall, $R$ and French, N. P. (1988) : 'The effect of farm manageunent sirategles on the Incldence of sheep strike in Britaln: a simulation analysis. Vet. Parasttol. 79. 341-57.

Freach, N. P.; Parkln T. D. H. and Morgan, B. L. (1808) : A case control study of blowily strike In lambs. Vet Rec; 19: 394-8.

Hira, P. R.; Agsad, R. M.; Okashah, G.;
Al-All, F. M.; Iqbal, J.; Mutawall, K. E. H.: Dlsney, R. H. L. and Hall, M. J. R. (2004) : Myliasls in Kuwalt: Nasocomial infections Caused By Luellla sericala And Megaselia scalarls, Am. J. Trop. Med. Hyg: 70, 386-9.

James, P. J.; Matchel, H. K.; Cockrum, 8. 5. and Aacell P. M. C. (1994) : Controlled release Insectuctide devices for protection of sheep against head strike caused by Lucilla cuprina. Vet Parasitol: 52.113-28.

Martin, W. B. and Altken, 1. D. (2000) : Diseases of sheep. 3rd ed. Oxford: Blackwell Sclence. 292-4.

O'Brien, D. J.; Morgan, J. P.; Lane, M. F.; O'Rellyy, P. F. and O'Nelll, S. J. (1897): A novel dips formulation of a synthetic per. ythrold (SP) for the control of blowly mylasls of sheep. Vet Parastiol: 69,145-50.

Radostls, O. M.; Gay, C. C.; Blood, D. C. Hinchcllf, K. W. (2000) : Veterinary medlcine. a lextbook of the diseases of cattle. shexp, pigs, goats and horses. Phlladelphla: W.E.Saunders, 1393-8.

Soulsby, E. J, L. (1988) : Helminths, Arthropods and Protozoa of Domestkated Antmals, $7^{\text {th }}$ Edition. Balllere Tindall.

Btarlc. J.; Zadnik, T.; Vidrth, $A$ and VerMez-Rntaj. A (2002) : Cutaneous Myiasis In Two Sheep. Slov. Vet, Res. 39. 243-50.

Urquhart, G. M.: Armour, J.; Duncen. J. L.; Dunn, $A$ M. and Jenninge F. $W$. (1087) : Veterinary Parasitology. $1^{\text {st }}$ Ed. Longman Sclentilic \& Tectunical. UK. 
Walker A (1894) : Arthropods of humans and domestic animals, $1^{\text {st }}$ Ed. Chapman\& Hall.
Wall $R$, and Smith K, E. (1996) : Coluur discrimunation by the sheep blowfly Lucilla sericata. Med Vet Entomol. 10 (3) 235-40. 